\section{STRUCTURAL ORGANIZATION AND STRUCTURAL INTEGRATION}

Lauer, Robert $\mathrm{H}$ "Toward a Sociological Theory of Development: A Structural Perspective," Rural Sociology 38:462-76.

1973 Perspectives on Social Change (Boston: Allyn and Bacon).

Merton, Robert $\mathrm{K}$

1968 Social Theory and Social Structure (New York: The Free Press).

Moore, Wilbert E.

1960 "A Reconsideration of Theories of Social Change," American Sociological Review 25:810-18.

1966 Social Change (Englewood Cliffs: Prentice-Hall).

Parsons, Talcott

1961 "Some Considerations on the Theory of Social Change," Rural Sociology 26:219-39.

1971 "Comparative Studies and Evolutionary Change," in Ivan Vallier, ed., Comparative Methods in Sociology (Berkeley: Univ. of California Press). Petras, James F.

1974 "Urban Proletariat Politics in Chile," The Insurgent Sociologist 4:5-14.

Portes, Alejandro

1974 "Modernity and Development: A Critique," Studies in Comparative International Development 9:247-79.

Smelser, Neil J.

1968 "Toward a Theory of Modernization," in Essays in Sociological Explanation (Englewood Cliffs: Prentice-Hall).

1973 Karl Marx on Society and Social Change (Chicago: Univ. of Chicago Press)

Zeitlin, Maurice

1973 "Chile: The Dilemmas of Democratic Socialism," Working Papers for a New Society 1:16-26.

Zeitlin, Maurice, Lynda A. Ewen, and Richard E. Ratcliff

1974 "New Princes for Old? The Large Corporation and the Capitalist Class in Chile," American Journal of Sociology 80:87-123.

\section{ROBERT H. HINGERS}

Univerity of Kansas

Mid-American Review of Sociology, 1976, Vol. 1, No. 2:33-43

\section{ABSTRACT}

Hillery's constructed types are used as a framework to develop a hypothesis regarding the relationship between forms of social organization and the integration and longevity of the group. The hypothesis is tested using: (1) failure rates of businesses and marriages, and (2) failure rates of variously structured intentional communities. Both tests support the hypothesis that communal organizations, which permit structural freewheeling, are more stable than formal organizations, which do not.

\section{INTRODUCTION}

Sociologists interested in the field of organizations, particularly community organization, have of late been presented with an empirical anomaly which appears with notable regularity in various societal frameworks. The commune, or intentional community, has again appeared on the American landscape quite visibly and has attracted the attention of a number of social commentators and sociologists (Fairfield, 72; French and French, 75; Kanter, 72, 73; Muncey, 73; Roberts, 71, 74; Veysey, 73; Zablocki, 71). Indeed, most sociologists interested in the intentional community recognize not only its contemporary appearance in the United States, both in terms of separatist organizations and as alternatives designed under the name of planned communities, but also on the international scene, particularly as it occurs in communist countries as an established form of social organization. Interestingly, however, most American sociologists have confined their inquiries to this continent while developing historical analyses and comparisons. The present article also makes no pretenses of comprehensive scope for a very good reason: American sociologists have not yet fully mapped nor understood this phenomena as it has occurred within our own societal framework.

The analysis presented here draws on the work of recent innovations in the vein of constructed typologies and community theory in America (Poplin, 72). The main thrust of this analysis dwells on the unique types of social integration which are associated with particular types of social 
organization. The presentation is a basic exploration of particular facets of social structural integration derived from the study of communal and formal organizations which are specifically relevant to the intentional community.

\section{THE CONSTRUCTED TYPES}

Social organization can be profitably analyzed according to a framework developed and recently elaborated by Hillery in his study of communal organizations (Hillery, 1968, 1971). The general taxonomy of human groups which Hillery constructed represents a classification system of structural types. The structural criteria which Hillery employs in differentiating human groups are primacy of organizational orientation to specific goals and degree of institutionalization. Primacy of organizational orientation to specific goals is suggested as particularly salient in formal organizations.

It should be noted that Hillery's use of the concept, "specific goal" is identical to that of Parsons. Parsons defines specific goals as those which are:

1. Identifiable

2. Capable of being used as input in another system

3. Amenable to contractual relations (Parsons, 1960:17)

Communal organizations are characterized as those groups which do not give primacy to specific goals. Examples are families and communities. Formal organizations are characterized as those groups which do give primacy to specific goals. Examples are firms and businesses. Both formal and communal organizations are highly institutionalized when compared to what Hillery calls expressive and informal groups.

Although Hillery maintains that the distinction between communal and formal organizations is one of kind rather than degree (i.e., a qualitative rather than quantitative distinction), one of Hillery's students has recently offered an alternative interpretation. Gottschalk proposes that: within the general classification of organizations there are two modes, the formal and the communal ... the differences between the two types of organizations are not absolute, they are differences of degree along a continuum between high and low specific goal orientation. However, the distribution of organizations along this continuum is not in the shape of a normal curve; it is bimodal. Organizations that occupy middling positions, between the modes, experience significant internal conflict, such as Hillery notes in the case of the monastic convent, between the 'worshipful' and the 'efficient' (Gottschalk, 1975:136).
Table 1

\section{A GENERAL TAXONOMY OF HUMAN GROUPS}

The system has primacy of orientation to specific goals.

\begin{tabular}{|c|c|c|}
\hline & Yes & No \\
\hline \multirow{6}{*}{ High } & FORMAL & COMMUNAL \\
\hline & State & Nation \\
\hline & Firm & Vill (village or city) \\
\hline & Local Business & Family \\
\hline & “Captive Communities" & Intentional Communities \\
\hline & Total Institutions & Limited Communities \\
\hline \multirow{3}{*}{ Low } & EXPRESSIVE GROUPS & INFORMAL GROUPS \\
\hline & Social Movements & Ethnic Groups \\
\hline & Crowds & Cliques \\
\hline
\end{tabular}

\section{MODES OF INTEGRATION AND ORGANIZATION}

Structural freewheeling is a functional feature of social systems which alleviates stress on the total system when the impact of change occurs in only certain aspects of the system. ${ }^{2}$ "Human groups are held together by symbolic connections, and the lack of mechanical or biological tissue joining individuals introduces a freedom in the structure of human social units which is unknown in mechanical or biological units . . . it is probably in light of these qualities that group integration should be viewed" (Hillery, 1968, 1970). Gottschalk contends that structural freewheeling, as it is based upon symbolic human ties; can be especially crucial in understanding the foci of cooperation (Gottschalk, 1975). The folk village, with its generalized cooperation system, allows any exchange which satisfies the parties involved. On the other hand, the city, with its contractualized cooperation, specifically enumerates the terms of an agreement. The specificity of contractual relations, Gottschalk maintains, is a social analog to mechanical interaction. Moreover, the mechanical interaction which contractual relations foster is tailored particularly to the production of specific goals, the defining characteristic of formal 
organizations. One might, then, suggest that contractual relations are the integrating symbolic ties of formal organizations.

If contracts are maximized in formal organizations, then may not structural freewheeling be maximized in communal organizations? ${ }^{3}$ Hillery has found that communal organizations are integrated by the practical convenience (if not the freewheeling) of interacting families who share common space, time and energy sources (Hillary, 1968:193). The reader should note that the above discussion does not imply that cities are like formal organizations and folk villages are like communal organizations. What is intended simply is that cities contain more formal organizations and hence contracts than folk villages. Neither should the reader construe the argument to mean that communal organization is uninstitutionalized. In fact, contracts also ensure the prolongation of structural freewheeling (i.e., the marriage "contract"), which, it might be noted, is the only contemporary contract which retains the original form of contract as described by Henry Maine in his Ancient Law (Maine: 1879).

Social organization in the large society, as we have conceptualized it, consists of two major classifications of human groups. Firstly, communal organization, which is primarily integrated according to the principle of structural freewheeling. Formal organizations, on the other hand, are primarily integrated by the specificity of contracts, which facilitates the production of specific goals. Another way of saying this is that the larger society is structurally bifurcated. This idea is not new. Marx wrote about a bifurcation in capitalist society in a somewhat similar fashion in his early writings (Bottomore, 1963).

Communal organization has an advantage of fluid structural freewheeling since practical convenience and affective ties are at the nexus of interaction, and behavior is not codified by contractual requisites of a highly specific nature. In this institutionalized setting, a certain amount of stability is ensured while the communal organization (organically) evolves appropriate and well-constructed channels of dealing with stress.

\section{Analysis of Communal and Formal Organizations}

Empirically, what would be expected given the different types of integration in our classification of organizations is that formal organizations will have a higher rate of demise than communal organizations. This theoretical expectation can be formulated and preliminarily tested, although quantitative data on the failure rates of intentional communities is unavailable. What is offered in lieu of an answer to why intentional communities fail is perhaps a more significant question: Do the types of social groups we have outlined as exhibiting different forms of symbolic integration also exhibit differential rates of stability? If so, indirect evidence may be available to further substantiate our theoretical argument concerning the fate of intentional communities. Indeed, Gottschalk suggests that

in intentional communities, the communal dimension finds expression not in the ideology, i.e., in high goal orientation towards an ideological goal, but in the crevices between, in the areas not regulated by either economic necessity or overtly ideological constructs.

From this perspective, the mechanisms of commitment identified and classified by Kanter are to be viewed as goal oriented, institutionalized and directed towards the attainment of the ideological goal of the community . . . according to this view, the mechanisms of commitment are acts performed in fulfillment of the contractual agreement between the members and the community (Gottschalk, 1975:90).

The basic question may thus be phrased in terms of the hypothesis: if a human group is a formal organization, it will have a higher likelihood of demise than a human group which is a communal organization.

One test of this hypothesis shall be a simple comparison of marriagedivorce rates and the rates of businesses started and discontinued during recent years in the United States. We would expect to find that businesses would fail at a higher rate than marriages if formal organizations are more likely to fail than communal organizations. It would be more appropriate to compare the longevity of communities and businesses, but no ready source of such data is available. On the other hand, using marriages rather than communities as communal organizations constitutes a stronger test of the theory, since communities are significantly longer lasting than individual marriages. Since adequate statistics on businesses are difficult to obtain, initial research only uncovered rough estimations.

Dun and Bradstreet, a business firm which collects the most comprehensive statistics pertaining to business failure and changes in rates of failure offer the following data:

In recent years, more than 400,000 firms are started annually, between 350,000 to 400,000 discontinued, and ownership or control is transferred in a slightly larger number. Each business day, more than 5,000 listings in the D. \& B. reference book are changed as new names are added and discontinued businesses deleted; credit 
and financial ratings revised up or down and name styles are altered (Dun and Bradstreet, 1972:2).

In other words, almost as many businesses are discontinued each year as are started. The turnover rate is one for one. Dun and Bradstreet attributes $93 \%$ of business failures during 1971 to inexperience and incompetence (Dun and Bradstreet, 1972).

Marriage and divorce rates are easier to obtain than business statistics. The following table enumerates rates from 1940 to 1969 . In the far righthand column are the ratio of marriages to divorces. One divorce for every three marriages is the highest divorce rate, while it has dropped as low as one for every six marriages in 1940. These statistics, as in the information for businesses, are annual turnover figures.

Table 2

Marriage and Divorce Rates in the United States: 1940-1969

\begin{tabular}{llrlcc}
\hline \hline Year & Marriages & Rate & Divorces $^{2}$ & Rate $^{3}$ & $\begin{array}{c}\text { Turnover } \\
\text { rate }\end{array}$ \\
\hline 1940 & $1,595,879$ & 12.1 & 264,000 & 2.0 & $6-1$ \\
1945 & $1,612,992$ & 12.2 & 485,000 & 3.5 & $3-1$ \\
1950 & $1,667,231$ & 11.1 & 385,144 & 2.6 & $4-1$ \\
1955 & $1,531,000$ & 9.3 & 377,000 & 2.3 & $4-1$ \\
1960 & $1,523,000$ & 8.5 & 393,000 & 2.2 & $4-1$ \\
1965 & $1,800,000$ & 9.3 & 479,000 & 2.5 & $4-1$ \\
1966 & $1,857,000$ & 9.5 & 499,000 & 2.5 & $4-1$ \\
1967 & $1,927,000$ & 9.7 & 523,000 & 2.6 & $4-1$ \\
1968 & $2,059,000$ & 10.3 & 582,000 & 2.9 & $3-1$ \\
1969 & $2,156,000$ & 10.6 & 660,000 & 3.3 & $3-1$ \\
\hline \hline
\end{tabular}

(World Almanac: 1972,67)

1 Includes estimates and marriage licenses for some states for all years.

2 Includes reported annulments.

3 Divorce rates for 1945 include Armed Forces overseas.

Clearly the evidence which has been gathered here supports the hypothesis advanced. Turnover rates for businesses are much higher than those for marriages. Admittedly, this is a cursory test of the relationship which was hypothesized. Nevertheless, preliminary verification has provided grounds for further research in terms of the theoretical framework briefly sketched in this paper. Whether it initially appears that the hypothesis is obvious or not is to argue ad hominim. This is a crude comparison, yet the crudity only emphasizes the extreme nature of the differences between the two types of systems which is, of course, the main thrust behind this discussion.

\section{HISTORICAL ANALYSIS OF THREE PARTICULARLY VIABLE ORGANIZATIONS}

Returning to the case of the intentional community, a number of the longer lived communities may be examined to test the hypothesis. We would expect the structure of the community to be related to its longevity. The American Shakers, the Perfectionists of Oneida, and the Roman Catholic Monasteries all provide useful information.

The American Shakers, who first formed communities in 1787, have barely survived into the 1970 's. The Shakers, who reached their largest membership through a number of revivals held before and after the economic crisis of 1837, at one time had from 5,000 to 8,000 members in some 18 societies or communities (Desroche, 1971:130-131). The Shakers may be seen as going through three sociological phases (Desroche, 1971). The first phase included the Shakers' beginnings as a French orgiastic millenarian movement through the death of Elder James Whittaker in 1787. Whittaker was the last original witness. The second phase occurred under the leadership of Elder Joseph Meacham, during which written rules and covenants were introduced as well as a series of "orders" or degrees of community membership. In the second phase a dualistic hierarchy (male-female) formed, and the Shakers experienced their greatest growth, coincident with their largest revivals, and also with the Owenite and Fourierist movements. The third phase started at the onset of the Civil War. The rituals and dances of the Shakers became rigidified and the movement slipped from the original fervor into spiritualism and social science. Elder Frederick Evans, the chief minister of this period, tried to implement noncelibate orders as a means of recruitment for the Shakers, but was, perhaps, too late.

For the Shakers, one of the cornerstones of their ideology was celibacy. For the continuance of the group, this policy presented severe problems. This belief along with an insistence on a "providential" and inactive manner of recruitment slowly brought to fruition the founder Mother Ann's prophecy of not having enough members, in the end, to bury their own dead. Whether or not the Shaker ideology could have incorporated a more active recruitment policy (of which there are signs in their 
caring for orphans) is a moot point. In fact, the Shakers did not assume such a position. This group was simply more interested in living its beliefs or, in essence, fulfilling the contractual agreement between the members and the community than in providing for an eventual crisis due to flagging membership.

The Perfectionists of Oneida are perhaps a clearer and better known example of the demise of communes. In 1848 John Humphrey Noyes started his community at Oneida, N.Y. on forty acres of neglected land. In January 1857, after their first annual inventory, they found themselves worth over 67 thousand dollars. By 1874, 654 acres of land near Oneida and 240 acres near Wallingford, Connecticut had been acquired. Oneida community's Perfectionists had built, by this time, what could only be called an economically sound community. In 1877 the tableware business was begun and by 1880 the Perfectionists were worth a half-million dollars.

After several lawsuits the community decided that in order to protect themselves all the property should be transferred to the four leading men-including John H. Noyes, Erastus Hamilton, William H. Woolworth, and Charles Otis Kellogg. The property remained in the hands of the four men until the demise of the experiment in 1879-1880. During the period in which Oneida disintegrated there were a few noteworthy events. John Humphrey Noyes, the community's leader, found it necessary to retire to Canada in 1877. By 1879 the community decided to end their complex marriage and reinstate monogamy or celibacy for the membership. At the start of 1881 Oneida community divided and became Oneida Community, Limited. In 1889 the village surrounding the business voted to change its name from "Community" to "Kenwood." By 1935 the term "community" was removed from the company's title. As the community lost its dedication to Noyes' ideology, the existing social structure the group had molded was transformed quite easily into. two separate organizations-the business and the settlement of families.

The instance of intentional community which is perhaps the most successful of any attempt is seen in the Roman Catholic monasteries. Monasteries have existed for centuries and show no signs of dying away in the near future. Perhaps the most significant feature of the monasteries when compared to the other cases mentioned and almost all other communes is the fact that they are affliated with a large-scale international, formal organization-the Roman Catholic Church. ${ }^{4}$ In respect to this affliation there is an intriguing implication. Typical community is seen as particularly stable since ideological articulation is through formal organizations. These structures remove and encase stress from the communal portion of the community. Only when ideological polarization spills over is the community truly in danger.

Exactly how the relationships between the monasteries and the formal organizational church hierarchy is managed, particularly since the ideological changes introduced at Vatican II, can be considered a fruitful research area in terms of intentional communities. Of course, any other intentional communities which generate such a structure would be even more significant in terms of research. Yet such a development appears to take relatively long periods of time, and the author knows of no such examples.

Intentional communities structurally embody unusually comprehensive ideological systems. This may inhibit what we have called structural freewheeling, an important element of the integration of typical communities. On the other hand, typical communities are bifurcated. The articulation of ideology is through formal organizations. Thus, communal organization is enabled to freewheel as changing situations demand. By this process stability is maximized in the social structure. Thus, the location of ideological articulation will influence the high expiration rates of both communes and formal organizations by limiting freewheeling. Optimal conditions for the survival of the intentional community apparently occur when there is a separation of the formal and communal aspects of the community, so that contractual arrangements do not impinge on structural freewheeling. This second test of the hypothesis also supports the notion that truly communal organizations, free from formal components, have greater longevity.

\section{CONCLUSIONS}

In businesses, the group chosen to represent formal organization, a significantly higher instability was noted in comparison to families, the group chosen to represent typical communal organization. Ninety-three percent of the businesses which failed were attributed to inexperience, a factor which is not nearly as volatile in communal organization. In particular, American stability seems to rest upon the autonomy of communal organization. Formal organizational membership, which carries relatively specific behavioral requirements (as does the commune) is voluntary and a mere adjunct to the maintenance of communal organization.

Placing what at first appears apparent (e.g., that families are more stable than businesses) into the framework discussed here results in a 
fertile transformation. Not only has this discussion brought us closer to understanding the fragility of intentional communities, but it has cast light on some basic principles of human integration and the differential stability of social organization. That is, one of man's more formidable creative tasks is exemplified by his efforts to alter the social structures in which he lives.

\section{NOTES}

1. Ideology is conceived of as empirical-evaluative beliefs as suggested by Parsons (Parsons, 1951: 349)

2. Hillery has recognized the bearing of the functional alternatives of Merton, the cultural lag of Ogburn, the social slippage of Stouffer, and the contradictory functional requirements of Sjoberg on the concept of structural freewheeling (Hillery, 1972).

3. Hillery has already confirmed the hypothesis that communal organizations maximize freedom relative to formal organizations. Although there is a conceptual overlap between structural freewheeling and freedom, structural freewheeling does not convey the subjective dimensions which the concept of freedom does. George Hillery, Jr., "Freedom and Social Organization: A Comparative Analysis," American Sociological Review, 1971, Vol. 36 (February): 51-65.

4. The primary concem with integration of organizations is not to obviate the external ties of an organization; to the contrary, our concern emphasizes their importance.

\section{BIBLIOGRAPHY}

Benson, Leonard G.

1963 National Purpose: Ideology and Ambivalence in America (Public Affairs Press, Washington, D.C.).

Desroche, Henri

1971 The American Shakers: From Neo Christianity to Pre-socialism (The University of Massachusetts, Amherst, Massachusetts)

Dun and Bradstreet

1972 The Failure Record Through 1971: A Comprehensive Study of Business Failures by. Industry, Location, Age, Size and Cause (Dun and Bradstreet, Inc., N.Y.).

Fairfield, Richard

1972 Communes USA: A Personal Tour (Penguin Books, Inc., Baltimore, Md.).

French, David and Elena

1975 Working Communally: Patterns and Possibilities (Russell Sage Foundation, N.Y.).

Gottschalk, Simon S.

1975 Communities and Alternatives: An Exploration of the Limits of Community Planning (Schenkman Publishing Co., Cambridge, Mass.)

Hillery, George A.

1968 Communal Organizations: A Study of Local Societies (University of Chicago Press, Chicago, Illinois).
1971 "Freedom and Social Organization: A Comparative Analysis," American Sociological Review Vol. 36 (February): 51-65.

1972 "Selected Issues in Community Theory," Rural Sociology Vol. 37 (December): 534-552.

Kanter, Rosabeth $\mathrm{M}$

1972 Commitment and Community: Communes and Utopias in Sociological Perspective (Harvard University Press, Cambridge, Mass.).

1973 Communes: Cresting and Managing the Collective Life (Harper and Row, N.Y.).

Lane, Robert

1962 Political Ideologies: Why the American Common Man Believes What He Does (The Free Press, N.Y.)

Maine, Sir Henry J. Sumners

1879 Ancient Law (H. Hotand Co., N.Y.).

Marx, Karl

1963 Early Writings (Trans. and Edited by T. B. Bottomore, C. A. Watts and Co., London).

Munsey, Raymond Lee

1973 Sex and Marriage in Utopian Communities (Penguin Books, Inc., Baltimore, Md.).

Nordhoff, Charles

1875 The Communistic Societies of the United States (Harper and Bros., N.Y.).

Noyes, John Humphrey

1870 History of American Socialisms (J. B. Lippincott and Co.).

Parsons, Talcott

1951 The Social System (London, Routledge).

1959 "An Approach to the Sociology of Knowedge," Transactions of the Fourth World Congress of Sociology IV (Louvain: International Sociological Association).

1960 Structure and Process in Modern Societies (Glencoe, Illinois, The Free Press).

Poplin, Dennis E.

1972 Communities: A Survey of Theories and Methods of Research (MacMillan Co., N.Y.).

Roberts, Ron E.

1971 The New Communes: Coming Together in America (Prentice-Hall Inc., Englewood Cliffs, N.J.).

Roberts, Ron E. and Robert Marsh Klos

1974 Social Movements: Between the Balcony and the Barricade (C. V. Mosby Co., St. Louis)

Shevky, Eshred and Wendell Bell

1955 Social Area Analysis (Stanford University Press).

Sorokin, Pitirim

1957 Social and Cultural Dynamics (Extending Horizon Books, Porter Sargent, Boston, Massachusetts).

Long, Luman H., Ed.

1971 World Almanac and Book of Facts (Newspaper Enterprises, N.Y.). 